\title{
Groundwater
}

\section{Impact of Rainwater Harvesting on Hydrological Processes in a Fragile Watershed of South Asia}

\author{
by Kaushal K. Garg ${ }^{1,2}$, K. H. Anantha ${ }^{1}$, A. Venkataradha ${ }^{1}$, Sreenath Dixit ${ }^{1}$, Ramesh Singh ${ }^{1}$, and Ragab Ragab ${ }^{3}$
}

\begin{abstract}
Agricultural water management (AWM) interventions play an important role in ensuring sustainable food production and mitigating climate risks. This study was carried out in a watershed located in a low rainfall (400-600 mm) region of western India. The Soil and Water Assessment Tool model was calibrated using surface runoff, soil loss, and reservoir storage levels, between the year 2000 and 2006. The investigation indicated that the various AWM interventions increased groundwater recharge from $30 \mathrm{~mm} / \mathrm{year}$ to $80 \mathrm{~mm} /$ year and reduced surface runoff from $250 \mathrm{~mm} /$ year to $100 \mathrm{~mm} /$ year. The intervention structures were refilled two to three times during the monsoon season depending on rainfall intensity and duration. The interventions have the advantage of building a resilient system by enhancing groundwater availability even in dry years, stimulating crop intensification and protecting the landscape from severe erosion. The results indicate that soil erosion has been reduced by more than 75\% compared to the nonintervention situation. Moreover, the AWM interventions led to the cultivation of 100-150 ha of fallow land with high-value crops (horticulture, vegetables, and fodder). Household income increased by several folds compared to the nonintervention situation. The study showed about $50 \%$ reduction in downstream water availability, which could be a major concern. However, there are a number of ecosystem trade-offs such as improved base flow to the stream and reduction in soil loss that should be considered. The study is of great importance to stakeholders to decide on the optimal design for AWM interventions to achieve sustainable development goals.
\end{abstract}

\section{Introduction}

Globally, agriculture and its allied sectors are a source of livelihood for about $60 \%$ of the population (de Janvry and Sadoulet 2020; FAO 2020). About 51 million $\mathrm{km}^{2}$ are under agriculture and pastures, comprising nearly $50 \%$ of global habitable land, to feed an increasing population with changing food habits (Duro et al. 2020). In addition, there are the negative effects of climate change on the environment and ecosystem services (Rockström et al. 2009; Bahar et al. 2020; Gerten et al. 2020). The pressure on freshwater resources has increased to keep pace with economic development. As a result, a number of river basins are facing severe water scarcity and rising transboundary and intrasectoral

\footnotetext{
${ }^{1}$ ICRISAT Development Center (IDC), ICRISAT, Patancheru, 502 324, India; k.garg@cgiar.org; k.anantha@cgiar.org; a.venkataradha@cgiar.org; s.ramesh@cgiar.org

${ }^{2}$ Corresponding author: ICRISAT Development Center (IDC), ICRISAT, Patancheru 502 324, India; k.garg@cgiar.org

${ }^{3}$ UK Centre for Ecology and Hydrology, Wallingford, UK; rag@ceh.ac.uk

Article Impact Statement: Agricultural water management interventions helped to build groundwater resilience and strengthened ecosystem services in the drylands.

Received November 2020, accepted March 2021.

(c) 2021 National Ground Water Association .

doi: $10.1111 /$ gwat.13099
}

conflicts (Hoekstra and Mekonnen 2012; Garg and Azad 2019; Abraham and Ramachandran 2020; Omer et al. 2020).

India is one of the fastest growing economies prompting changes in food habits and lifestyles, which require more resources (Michler 2020). Per capita freshwater availability in India has declined from $5177 \mathrm{~m}^{3}$ in 1951 to $1545 \mathrm{~m}^{3}$ in 2011 due to the increase in population from 361 million in 1951 to 1250 million in 2011 (Wani et al. 2014). There is limited scope to expand irrigable land with declined water resource availability (Mukherjee et al. 2018; Ali et al. 2019). Agriculture in the drylands is largely supported by groundwater resources (Garg et al. 2020a, 2020b). Currently, India withdraws about $250 \mathrm{~km}^{3}$ of freshwater annually from groundwater sources, which is the highest in the world (Gleeson et al. 2016; Government of India 2019). Groundwater constitutes two-third of the total irrigated area in the country (Green et al. 2020). A large portion of cultivated area in the country is rainfed with low productivity of 1-1.5 t/ha (Rao et al. 2015). These areas face frequent droughts and witness acute moisture stress during critical crop growth stage, making agriculture vulnerable to production risks (Wani et al. 2011; Singh et al. 2014; Garg et al. 2020a). Despite these challenges, there is considerable scope to enhance productivity in rainfed agriculture through 
suitable technological interventions (Gerten et al. 2020; Anantha et al. 2021a).

In this context, agricultural water management (AWM) interventions have attracted attention in addressing risks in small-scale production systems in Asia and Africa (de Fraiture et al. 2010; Gordon et al. 2010; Garg et al. 2011; Kadyampakeni et al. 2015; Anantha and Wani 2016; Adimassu et al. 2017; Abera et al. 2019). The focus has been on landscape restoration through the constructing of water infiltration structures as well as biological measures (Adimassu et al. 2017; Abera et al. 2019; Kato et al. 2019; FAO 2020; Anantha et al. 2021b). Adopting a holistic resource management approach through integrated watershed development has paid generous dividends in rainfed areas and proved capable of solving and positively addressing many technological, natural, social, and environmental issues in dryland ecosystems (Rockström et al. 2010; Garg et al. 2011, 2012; Wani et al. 2011; Garg and Wani 2012; Singh et al. 2014; Anantha and Wani 2016; Garg et al. 2020a).

Since 1990, the Government of India, with support from several funding agencies, has invested more than US $\$ 14$ billion on its Integrated Watershed Management Program (Mondal et al. 2020; Anantha et al. 2021b). The program has helped enhance resource conservation to benefit a wide range of stakeholders in terms of ensuring food, income, and improving livelihoods (Barron et al. 2015). However, there is a poor documentation of the impacts of these interventions on the environment despite the huge investments made over three decades. This has been largely due to a lack of focus on data generation on key indicators such as hydrology, biophysical, and socio-economic changes to understand the hydrological processes in different agro-ecological regions. Most of the hydrological data are available at river basin/large-scale catchment area, which are difficult to downscale to smaller areas (Glendenning et al. 2012) as there is almost no information available at the mesoscale (500-5000 ha) landscape. Moreover, there is a poor understanding of the impact of upstream landscape development on downstream ecosystem services and its trade-offs.

Against this background, this study describes an integrated watershed approach adopted in one of the degraded landscapes of Bundi district of Rajasthan State in western India and quantifies its impact on watershed hydrology, land degradation, land use, crop yield, and economics between the years 2000 and 2006. Intensive field data on various biophysical, hydrological, and landuse parameters were collected. Further, a Soil and Water Assessment Tool (SWAT) was applied to compute water balance components. The study's findings are critical to refine interventions and improve investments in AWM and to sustain different ecosystem services. The objectives of the study are to: (1) analyze the impact of various AWM interventions on groundwater recharge, land-use change and crop productivity at uplands; and (2) assess freshwater availability and sediment load at downstream locations.

\section{Materials and Methods}

\section{Description of the Study Area}

This study was conducted on a fragile watershed (Govardhanapura-Thana watershed) with undulating topography in Bundi district $\left(25.58^{\circ} \mathrm{N} ; 75.41^{\circ} \mathrm{E}\right)$ of Rajasthan state, western India (Pathak et al. 2013). The study watershed covers 4800 ha and a population of 1800 (Figure 1). About a third of the total geographical area in the region is under degraded landscapes (Pathak et al. 2007, 2013). Rainfall in the region ranges between $400 \mathrm{~mm}$ and $600 \mathrm{~mm}$ annually and potential evaporation demand is 1800-2000 mm (Sharma et al. 2018). Agriculture and allied sectors are the main sources of livelihood and are largely dependent on locally harvested surface runoff and groundwater resources for domestic and agricultural use (Pathak et al. 2013).

The water-holding capacity of the soil is medium to low and its soil organic carbon is poor $(<0.5 \%)$. The landscape is undulating at upstream locations which are rangelands with a $2-5 \%$ slope whereas the valley of the watershed consists mainly of farm lands (Pathak et al. 2013). Sorghum (Sorghum bicolor), pearl millet (Pennisetum glaucum), maize (Zea mays), and pigeonpea (Cajanus cajan) are the major crops grown during the rainy season (kharif, June to October); and mustard (Brassica nigra), chickpea (Cicer arietinum), and wheat (Triticum aestivum L.) are grown with supplemental irrigation during the post-rainy season (rabi, November to March). In addition, livestock plays an important role in the livelihood system of the watershed (Wani et al. 2014).

International Crops Research Institute for the SemiArid Tropics (ICRISAT) and its partners developed this watershed as a study site between 1999 and 2005. Prior to this, the site was beset with acute water shortage, land degradation, and poor agricultural and livestock productivity (Pathak et al. 2013). More than 90\% of total agricultural land in the watershed was rainfed with mono-cropping. Crops suffered from water scarcity and experienced moisture stress even during the rainy season due to long dry spells (5-7-day dry spells), usually occurring five to seven times in a season. Average crop productivity ranged between $1000 \mathrm{~kg} / \mathrm{ha}$ and $1500 \mathrm{~kg} / \mathrm{ha}$ in sorghum/maize/pearl millet and between $200 \mathrm{~kg} / \mathrm{ha}$ and $300 \mathrm{~kg} / \mathrm{ha}$ in pigeonpea (Pathak et al. 2013; Wani et al. 2014).

A wide range of AWM interventions have been implemented both at community and individual field scales. The most common in situ interventions are contour and graded bunds in the fields, which reduce travel distance, minimize the velocity of runoff, and allow more water to percolate into the fields (Garg et al. 2011). Ex situ interventions, such as the renovation of village tanks, check dams, check walls, percolation ponds, and others, harvest significant amount of surface runoff from uplands and facilitate groundwater recharge (Singh et al. 2014; Garg et al. 2020a). In addition to the interventions implemented by ICRISAT and its partners, a number 


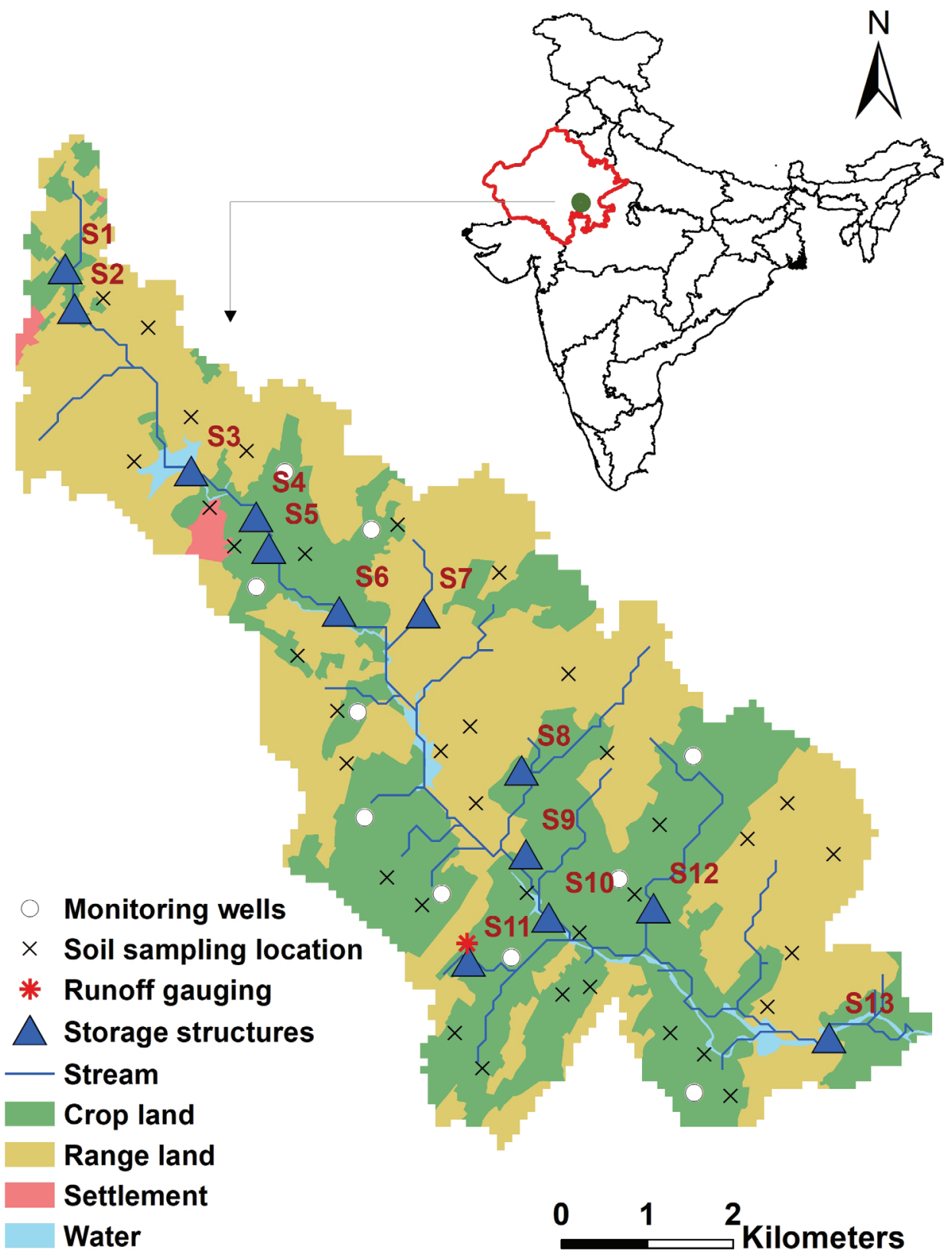

Figure 1. Location of the study area along with the stream network, water storage structures, and land use in Govardhanapura-Thana Watershed, Bundi District, Rajasthan, India.

of other state and central government schemes were converged between 2006 and 2010, altogether creating 1.5 million $\mathrm{m}^{3}(\mathrm{MCM})$ of water storage capacity (Pathak et al. 2013). Figure 1 shows the location of the different AWM storage structures developed from the year 2000 onwards.

The total water harvesting capacity of existing AWM interventions is equivalent to $320 \mathrm{~m}^{3} / \mathrm{ha}(32 \mathrm{~mm}$ of the storage capacity) in the watershed. Out of the 13 water storage structures, there were three major structures with a combined capacity to harvest $1.35 \mathrm{MCM}$. An earthen embankment of 3-5 m wide was constructed across the slope to harvest surface runoff from upstream sites and a masonry outlet spillway was constructed for the safe disposal of excess water (Pathak et al. 2013; refer Figure 2). These structures together have a water spread of 90 ha. Farmers store water during the rainy period and cultivate crops in the tank beds during the postrainy period using residual soil moisture and supplemental irrigation from wells. In addition, small to medium-sized storage structures were constructed following the ridgeto-valley approach. In addition to various ex situ AWM interventions, there was emphasis on integrated crop management practices including soil test-based fertilizer application, introduction of improved crop cultivars, and integrated pest, disease, and weed management through farmer participatory demonstrations and capacity building (Pathak et al. 2013). 

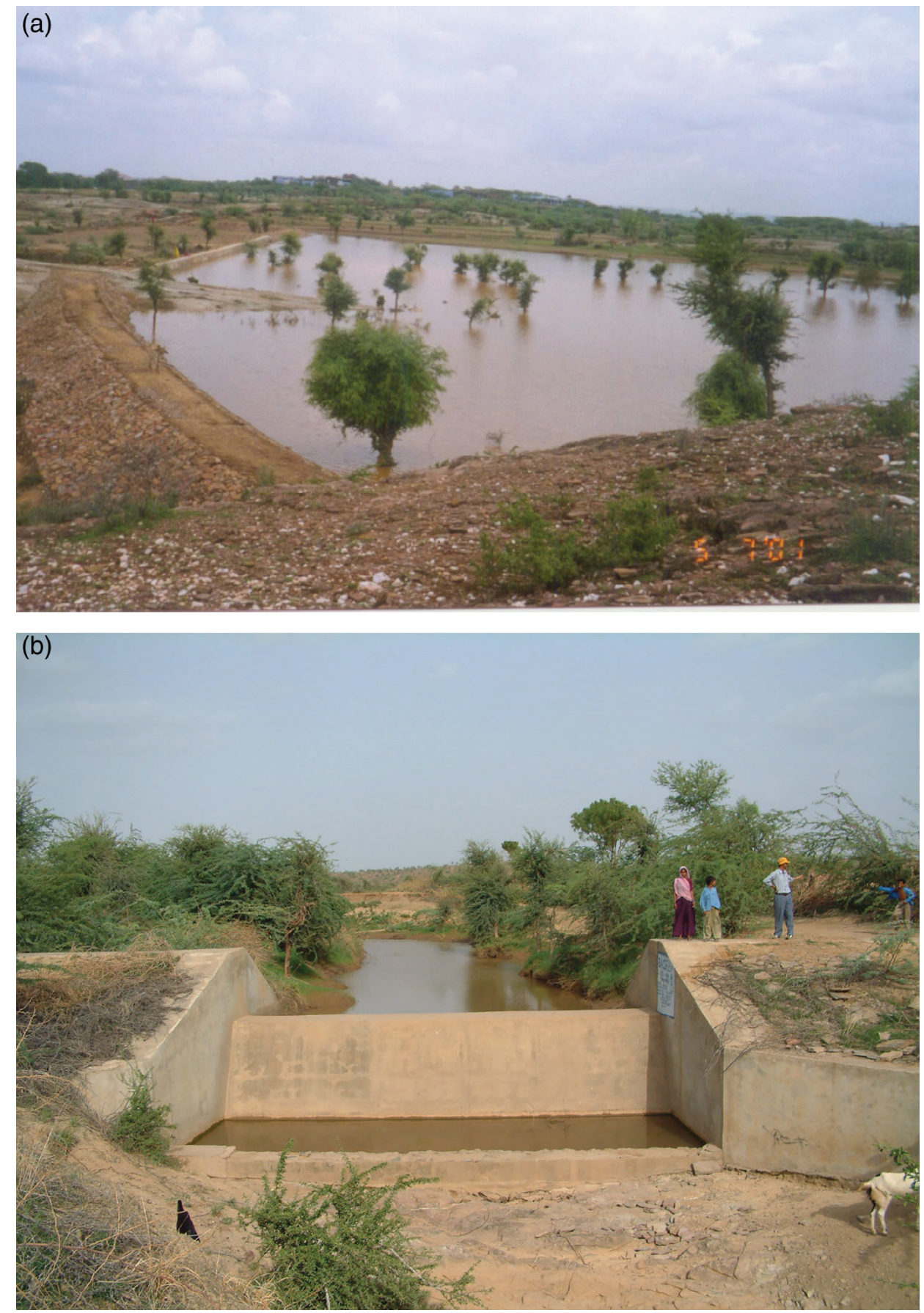

Figure 2. The village tank constructed for harvesting runoff using (a) masonry and earthen embankments and (b) check dam on a stream.

\section{Data Monitoring}

A total of 36 agricultural fields were identified to characterize the soil's physical and chemical properties following a systematic random sampling method. The soil analysis was meant to ascertain soil fertility in the farmers' fields as well as their water-holding capacity. Soil samples were collected at $0-15 \mathrm{~cm}, 15-30 \mathrm{~cm}$, and $30-60 \mathrm{~cm}$ depths from 36 locations in the watershed to analyze the texture, bulk density, field capacity, and permanent wilting point. Another 36 samples across the watershed were collected to analyze the soil nutrient status from the top soil $(0-15 \mathrm{~cm})$. Information on soil depth was derived based on farmers' experience as indicated in the survey.

The location and storage capacity of structures constructed during different periods were recorded through a topography survey. The elevation of the landscape was measured through a "total station" survey instrument and a contour map developed, based on which the water harvesting capacity was measured through Simpson's rule (Biswadeep 2015; Takal et al. 2017). Runoff at one of the micro-watersheds was measured using an automatic gauge recorder between 2002 and 2006 (Figure 1). A 
mechanical type stage recorder was installed at the outlet of the micro-watershed receiving drainage from 27 ha; the stage recorder was programmed to measure data at 30min intervals. The unit does smart sampling by linking the runoff sampling intervals to the sediment load (Black and Luce 2013; Pathak et al. 2016). During the runoff, water flowing at hourly intervals was pumped automatically and stored in separate containers. To measure soil loss, water samples collected during runoff events were analyzed in a laboratory for sediment concentration. Each runoff event hydrograph was divided into 60-min time segments and sediment concentration data was superimposed on the runoff hydrograph to estimate soil loss. This was computed by multiplying the volume of segment runoff by sediment concentration (Pathak et al. 2016). Water levels in one of the check dams (S11) were monitored manually on a daily time scale during the rainy season between 2002 and 2005.

The water table in 10 wells in the treated watershed (where AWM interventions were implemented) and 10 wells in the nearby control watershed (without treatment) was monitored between 2003 and 2005. The location of the wells in the treated watershed are shown in Figure 1. In addition, data on the number of pumping hours, crop yield, and cost of cultivation were recorded from selected farmers' fields for different crops between 2002 and 2006. To estimate crop yields, crop cutting studies were undertaken on a $5 \mathrm{~m} \times 5 \mathrm{~m}$ area and grain yield was estimated during the crop harvest (Tek et al. 2016).

\section{Hydrological Modeling}

\section{Model Setup and Parameterization}

SWAT is a semi-process based hydrological model that has been widely used for water resource assessment, and to study the impact of changes in land use and AWM interventions at catchment and basin scales (Arnold et al. 2012; Dile et al. 2016a, 2016b; Woldesenbet et al. 2017, 2018; Worku et al. 2017; Mekonnen et al. 2018; Berihun et al. 2020; Horan et al. 2021). The model's flexibility enables to parameterize local scale AWM interventions along with land topography, soil types, and land-use details. A digital elevation model was downloaded from the global database (Aster $30 \mathrm{~m}$ resolution). A soil map was created based on the measurements obtained from 36 samples collected from the watershed and provided as input to the model (Table 1). A land-use map of 2010 was classified using remote sensing techniques. The total 4800 ha area was divided into 37 sub-basins and 85 Hydrological Response Units (HRUs). A total of 13 reservoir nodes were added into the model, which represented the actual ex situ interventions, their storage capacity, and submergence area based on actual measurements. Eleven years' rainfall (1999-2010) and other meteorological parameters (maximum and minimum temperature, relative humidity, wind speed, and solar radiation) were provided to the model on a daily time scale.
The total landscape of the watershed was divided into three categories - agriculture, rangeland, and settlements. Information on agriculture management practices was provided as an input to the management files. Maize was grown as a rainy season crop under rainfed conditions and winter wheat was chosen in the post-rainy season. Tillage operations, date of sowing and harvesting, and fertilizer application data were provided according to the survey details. For the wheat crop, five irrigations were given using a shallow aquifer as a source of water. The model was run between 1999 and 2010. Model calibration was done based on observed surface runoff, soil loss measured from a micro-watershed, water level in one of the check dam sites and water table data. The model was run with and without the structural interventions. To simulate a nonintervention scenario, the reservoirs were removed from the model simulation and the model was run for the same period (1999-2010).

\section{Analysis of Water Balance Components}

As rainfall is the only source of water, it was partitioned into different water balance components.

Rainfall data were analyzed on a daily, monthly, and yearly time scale for the study period. To understand the intensity of rainfall distribution, daily data were classified into four major categories (low $=<10 \mathrm{~mm}$; medium $=10-30 \mathrm{~mm}$; high $=30-50 \mathrm{~mm}$, and very high $=>50 \mathrm{~mm})$ (Rao et al. 2013). Major water balance components (runoff/outflow, groundwater recharge, base flow, and evapotranspiration) were computed from the calibrated SWAT model. The result was summarized and classified as per the India Meteorological Department's specification (Rao et al. 2013) for a dry year (rainfall $<20 \%$ of long-term average); normal year (rainfall $\pm 20 \%$ of long-term average), and wet year (rainfall $>20 \%$ of long-term average).

\section{Results}

\section{Soil Properties and Climate}

\section{Soil Properties}

Table 1 describes layer-wise physical properties of the soil in the study watershed. Soils were characterized by their high sand content ranging from 56 to $70 \%$. The percentage of sand increased from the $0-15 \mathrm{~cm}$ layer to $30-60 \mathrm{~cm}$ layer. Gravel content ranged from 5 to $30 \%$ and its fraction increased with depth. Field capacity and permanent wilting point were found to be $0.18-0.21 \%$ and $0.09-0.11 \%$ (volume basis), respectively, indicating that water-holding capacity is $0.10 \mathrm{~m}$ per meter of soil.

\section{Rainfall Characterization}

The long-term rainfall data of Bundi district between 1985 and 2010 shows that annual average rainfall in the district was $562 \mathrm{~mm}$ with a significant year-to-year variability (Figure 3a). The average number of rainy days in a year was 35 (with more than $2.5 \mathrm{~mm}$ rainfall/day). 
Table 1

Biophysical Properties of the Soil in the Watershed (All These Values Were Assigned to the Model as Input)

\begin{tabular}{|c|c|c|c|c|c|c|c|c|}
\hline $\begin{array}{l}\text { Soil layer } \\
\text { depth }(\mathrm{cm})\end{array}$ & $\begin{array}{c}\text { Gravel } \\
(\%) \\
\text { ROCK }\end{array}$ & $\begin{array}{c}\text { Coarse } \\
\text { Sand }(\%) \\
\text { SAND }\end{array}$ & $\begin{array}{c}\text { Fine } \\
\text { Sand }(\%) \\
\text { SAND }\end{array}$ & $\begin{array}{c}\text { Silt (\%) } \\
\text { SILT }\end{array}$ & $\begin{array}{c}\text { Clay }(\%) \\
\text { CLAY }\end{array}$ & $\begin{array}{c}\text { Available } \\
\text { Water } \\
\text { Content } \\
(\mathbf{m} / \mathbf{m})\end{array}$ & \begin{tabular}{c}
\multicolumn{1}{c}{ Field } \\
Capacity \\
$\left(\mathrm{m}^{3}\right.$ Water $/ \mathbf{m}^{3}$ \\
Soil $)$
\end{tabular} & $\begin{array}{c}\text { Permanent } \\
\text { Wilting Point } \\
\left(\mathbf{m}^{3} \text { Water } / \mathbf{m}^{3}\right. \\
\text { Soil })\end{array}$ \\
\hline $0-15$ & $9(7)$ & $15(10)$ & $41(7)$ & $30(9)$ & $14(5)$ & 0.090 & $0.190(0.040)$ & $0.10(0.020)$ \\
\hline $15-30$ & $5(5)$ & $14(10)$ & $37(8)$ & $31(8)$ & $18(6)$ & 0.10 & $0.210(0.040)$ & $0.11(0.020)$ \\
\hline $30-60$ & $30(4)$ & $48(9)$ & $22(8)$ & $21(8)$ & $9(5)$ & 0.09 & $0.180(0.020)$ & $0.090(0.010)$ \\
\hline
\end{tabular}

Notes: Sample size for each layer $(n=3)$. Figures in parentheses show standard deviation from mean.
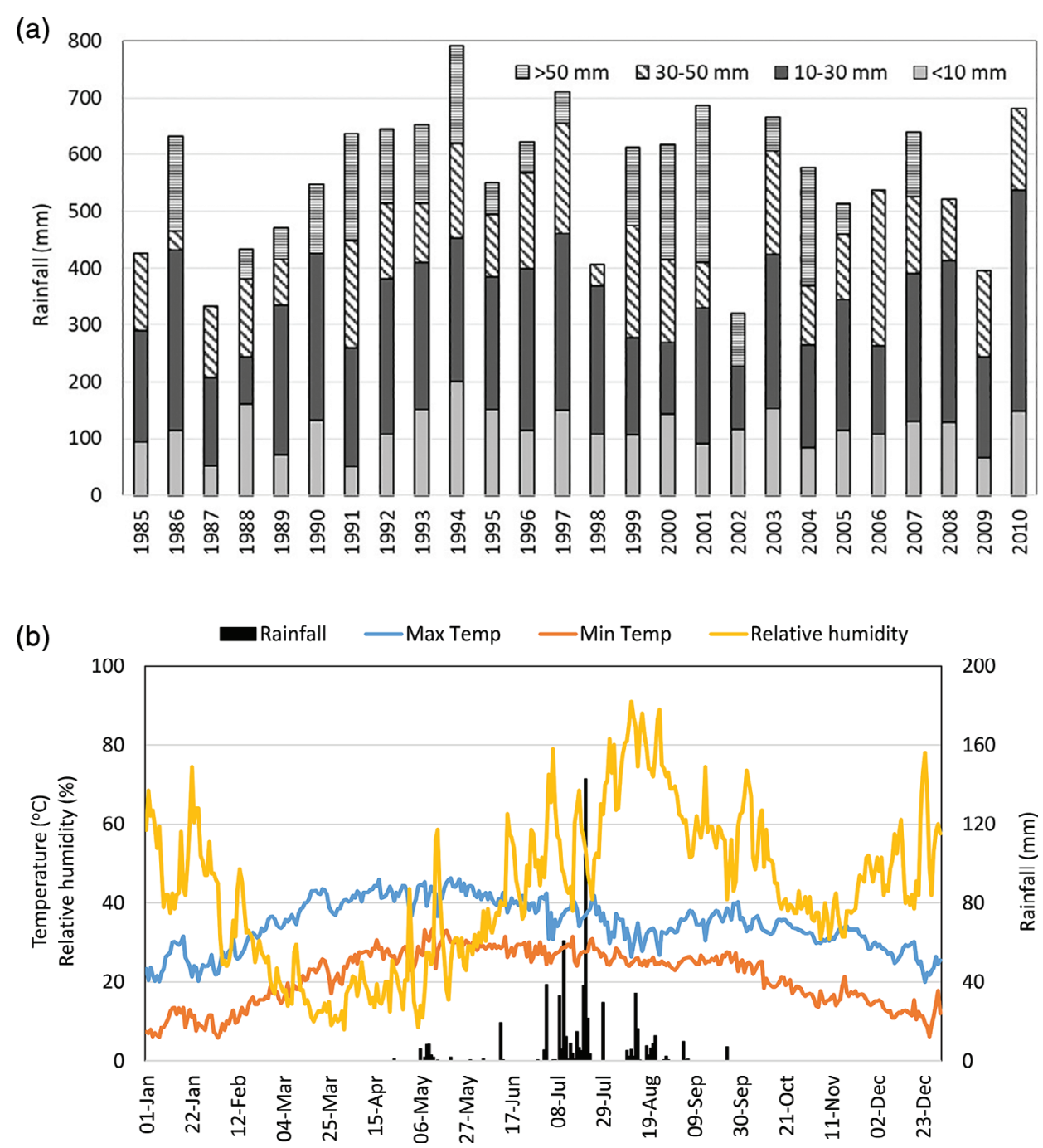

Figure 3. (a) Temporal variability of rainfall between 1985 and 2010 along with intensity distribution; and (b) variation in maximum and minimum temperature, relative humidity, and rainfall on a daily scale for 2000 .

Of these 35 days, 18 days received rainfall of less than $10 \mathrm{~mm}, 13$ days had rainfall between $10 \mathrm{~mm}$ and $30 \mathrm{~mm}$, and 3 days received between $30 \mathrm{~mm}$ and $50 \mathrm{~mm}$, and one event that received more than $50 \mathrm{~mm}$. With this distribution, a total of $118 \mathrm{~mm}$ of rainfall was received from low intensity events $(<10 \mathrm{~mm}), 230 \mathrm{~mm}$ from medium intensity $(10-30 \mathrm{~mm})$, and $125 \mathrm{~mm}$ from highintensity events $(30-50 \mathrm{~mm})$. Moreover, $90 \mathrm{~mm}$ rainfall was received through very high-intensity events of greater than $50 \mathrm{~mm}$.

Figure $3 b$ explains the variability in maximum and minimum air temperature, relative humidity, and rainfall for the selected year (2000). The study area was characterized by three predominant seasons: (1) rainy season from June to October which is hot and humid; (2) winter season from November to March which is cold 
Table 2

Model Parameterization: Initial and Final Values Given Before and After Calibration

\begin{tabular}{|c|c|c|c|c|}
\hline Variable (Unit) & $\begin{array}{l}\text { Parameter } \\
\text { in SWAT }\end{array}$ & $\begin{array}{l}\text { Initial } \\
\text { Value }\end{array}$ & $\begin{array}{l}\text { Final } \\
\text { Value }^{1}\end{array}$ & Source \\
\hline Organic carbon $(\%)$ & SOL_CBN & - & $0.4(0.2-0.6)$ & Measured \\
\hline Soil depth (m) & SOL_Z & - & $0.5(0.1-0.8)$ & Surveyed \\
\hline Saturated hydraulic conductivity $(\mathrm{mm} / \mathrm{h})$ & SOL_K & - & $2.0-8.0$ & $\begin{array}{l}\text { Estimated by } \\
\text { Pedo-transfer function } \\
\text { (Schaap et al. 2001) }\end{array}$ \\
\hline Curve number $(-)$ & $\mathrm{CN}$ & 70 & $65-75$ & Calibrated \\
\hline $\begin{array}{l}\text { Hydraulic conductivity of the reservoir's bottom } \\
(\mathrm{mm} / \mathrm{h})\end{array}$ & RES_K & 8.0 & 12.5 & Calibrated \\
\hline $\begin{array}{l}\text { Groundwater upward flux to the root zone } \\
\text { (revap coefficient) }(-) \text { for shallow aquifer }\end{array}$ & GW_REVAP & 0.02 & 0.2 & Calibrated \\
\hline $\begin{array}{l}\text { Threshold depth of upward water flux to the root } \\
\text { zone (revap) in shallow aquifer (mm water) }\end{array}$ & REVAP_MN & 1 & 0.3 & Calibrated \\
\hline Channel erodability factor $(-)$ & CH_EROD & 0.0 & 0.5 & Calibrated \\
\hline Channel cover factor $(-)$ & CH_COV & 0.0 & 0.5 & Calibrated \\
\hline USLE equation support practice factor $(-)$ & USLEE_P & 1.0 & 0.5 & Calibrated \\
\hline
\end{tabular}

${ }^{1}$ Data in parentheses show minimum to maximum range of parameter value.

(a)

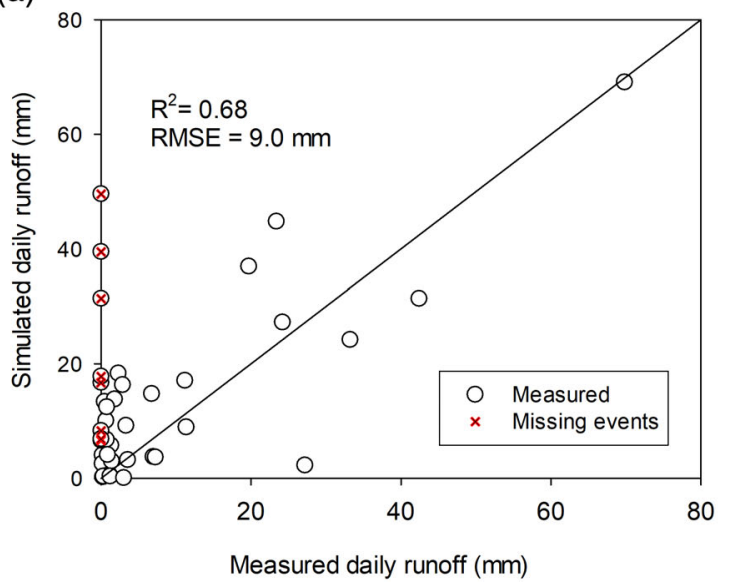

(b)

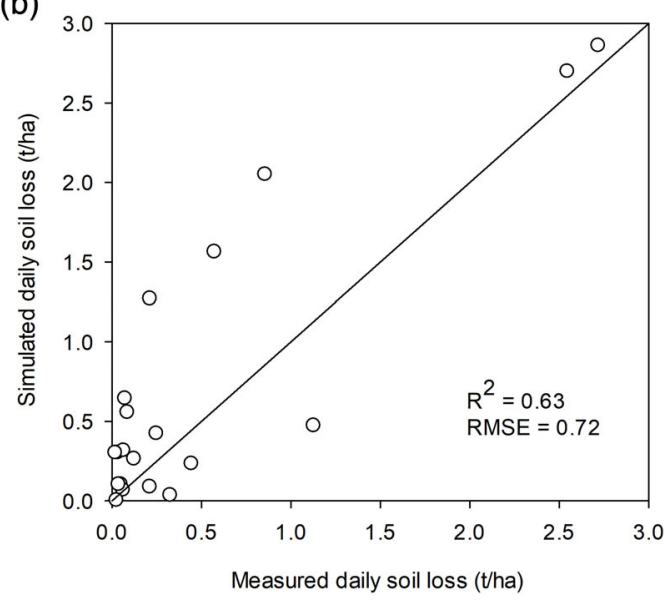

Figure 4. Comparing daily simulated (a) surface runoff and (b) soil loss with measured data at the micro-watershed between 2002 and 2006. The red crosses indicate missing data from runoff measurements.

and dry; and (3) summer season from March to June which is hot and dry. The highest temperature reached was $45^{\circ} \mathrm{C}$ in May while the minimum temperature of $6{ }^{\circ} \mathrm{C}$ was recorded during December and January. August was the most humid month with relative humidity $>80 \%$ while it was less than $20 \%$ during March to May. Data also showed that more than $85 \%$ of the rainfall in 2000 was concentrated in July and August.

\section{Model Performance}

Table 2 shows the calibrated parameter values to capture the mesoscale hydrology of the study watershed. Organic carbon ranged between $0.2 \%$ and $0.6 \%$ with a mean of $0.4 \%$. The average soil depth of the landscape was $0.5 \mathrm{~m}$, which varied from $0.1 \mathrm{~m}$ to $0.8 \mathrm{~m}$. Saturated hydraulic conductivity which was derived using pedo-transfer function, ranged from 2 to $8 \mathrm{~mm} / \mathrm{h}$. Table 2 shows the other calibrated parameters (CN, GW_REVAP, RES_K, and REVAP_MN) controlling hydrological processes and those that control soil dynamics (CH_EROD, $\mathrm{CH}-\mathrm{COV}$, and USLE_P). Hydraulic conductivity of the reservoir's bottom and curve number was found sensitive toward runoff generation.

Figure 4a compares the simulated surface runoff of a micro-watershed (27 ha, refer to Figure 1 for gauging location) with observed daily surface runoff between 2002 and 2006. The model simulated surface runoff was in agreement with observed data for both low and high-intensity rainfall. Root Mean Square Error (RMSE) and $R^{2}$ of simulated and observed values were $9 \mathrm{~mm}$ and 0.68 , respectively. However, there was missing data (indicated by a red $\mathrm{X}$ ) during the monitoring period due to field related constraints.

Figure $4 \mathrm{~b}$ compares simulated soil loss with measured values between 2003 and 2006. Out of the 23 events, 
(a)

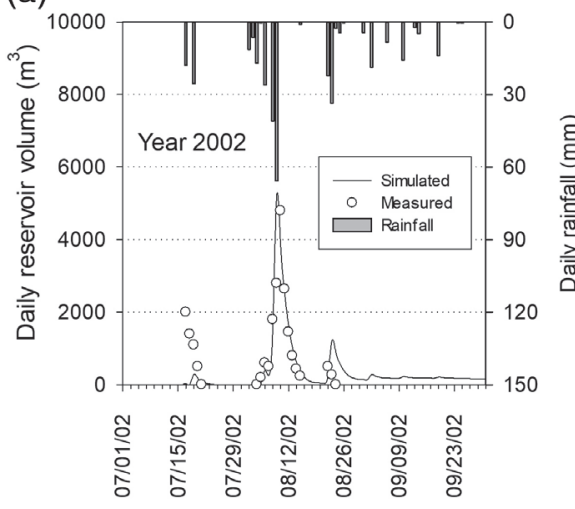

(c)

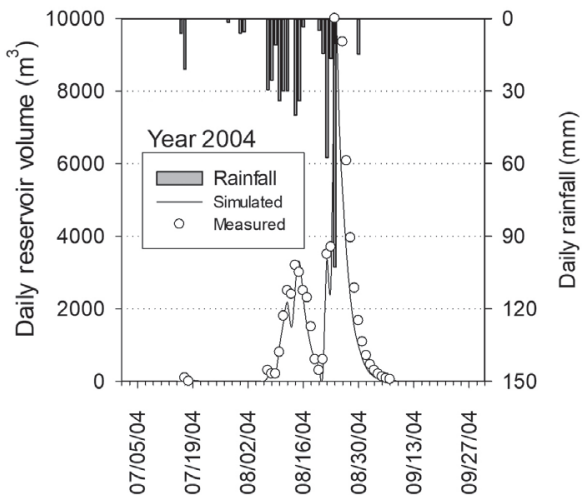

(b)

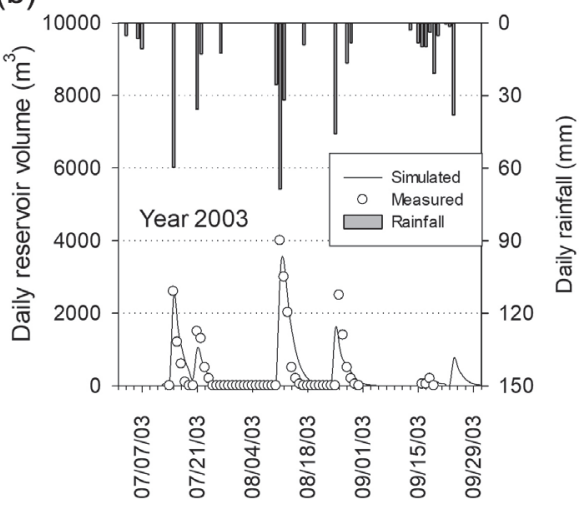

(d)

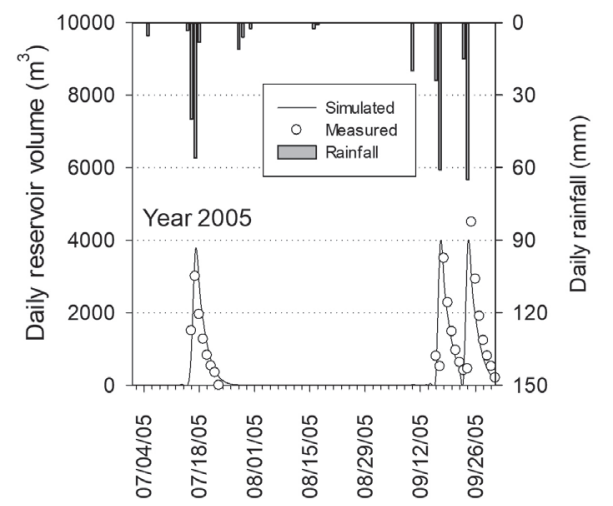

Figure 5. Comparing simulated reservoir volume with measured data for S11 on daily time scale for years (a) 2002; (b) 2003; (c) 2004; and (d) 2005.

average soil loss measured from the micro-watershed was $0.4 \mathrm{t} / \mathrm{ha}$ compared to $0.6 \mathrm{t} / \mathrm{ha}$ in the simulated model, and $R^{2}$ was found to be 0.62 . It was very difficult to perfectly match the simulation with the measured data as sediment transport is a very complex phenomenon. However, the model was able to simulate soil loss with high runoff events but was overestimating during small and medium rainfall intensity events.

Figure 5a-d compares the simulated daily reservoir storage $\left(\mathrm{m}^{3}\right)$ of structure number S11 during 2002, 2003, 2004, and 2005 with observed data. Both simulated and observed data followed a similar pattern. However, for some of the events, the simulated values were slightly underestimated but the overall performance of the model in predicting reservoir volume was in close agreement with the observed value. Data recorded for most of the events were in agreement with the simulated results.

\section{Water Balance Components}

Major water balance components (groundwater recharge, base flow, outflow, and Evapotranspiration (ET)) for the two scenarios, with and without interventions, are presented for dry, normal, and wet years (Figure 6). Of the 11 years, five were normal years, three were wet, and three were dry. The rainfall in normal years was $500 \mathrm{~mm}$ while it was $350 \mathrm{~mm}$ in dry years and $630 \mathrm{~mm}$ in wet years. The simulation results suggested

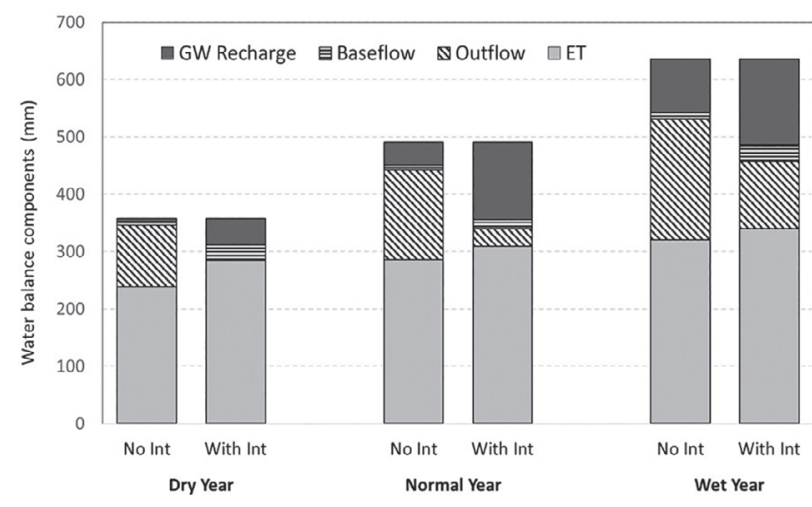

Figure 6. Simulated water balance components (groundwater recharge, base flow, outflow, and ET) with intervention and without interventions during dry, normal, and wet years based on a 11-year model simulation.

that ET was the major consumer of monsoonal water balance in all the years. In the absence of an intervention, in dry years, of the $350 \mathrm{~mm}, 250 \mathrm{~mm}$ was utilized as ET and the rest of the water-generated outflow $(80 \mathrm{~mm})$ and approximately $20 \mathrm{~mm}$ was recharged in the groundwater. After the intervention, the runoff generated was harvested in the storage structures and the outflow was found to be negligible. In situ interventions also enhanced soil moisture availability and flow toward actual ET increased 


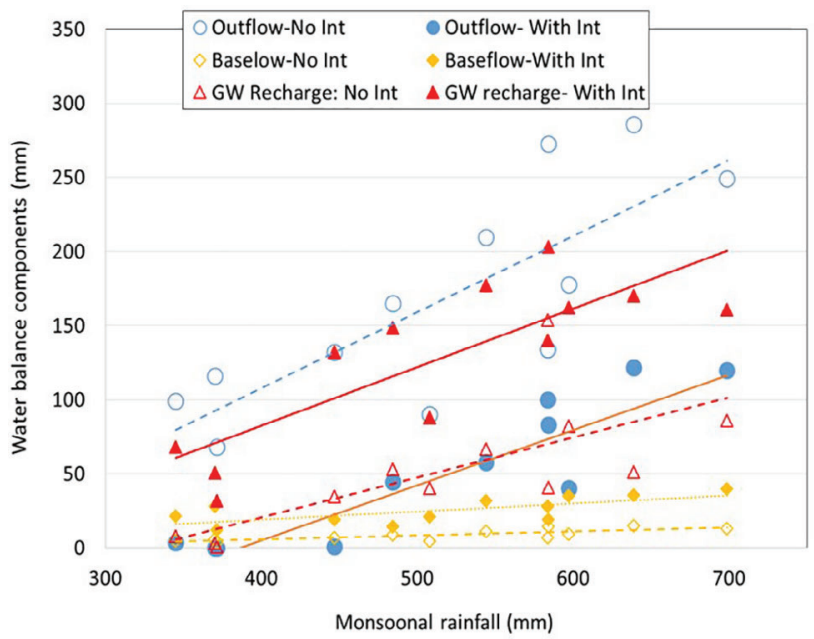

Figure 7. Relationship between rainfall and outflow, base flow, and groundwater recharge under intervention and nonintervention conditions, based on a 11-year model simulation.

within the monsoon period $(50 \mathrm{~mm}$ increase). During normal years, about $60 \%$ of rainfall received was utilized as ET within the monsoon period. Of the $150 \mathrm{~mm}$ of surface runoff which left the watershed boundary before the intervention, about $100 \mathrm{~mm}$ was harvested by ex situ interventions and enhanced groundwater recharge while about $50 \mathrm{~mm}$ spilled out. In wet years in the absence of interventions, total rainfall received was split into 50\% ET, $40 \%$ outflow, and $10 \%$ toward groundwater recharge, which saw a change to 55\% ET, $20 \%$ outflow, and $25 \%$ as groundwater recharge following project interventions.

Figure 7 shows the relationship between rainfall and outflow, base flow, and groundwater recharge in both intervention and nonintervention scenarios. A positive relationship between outflow and groundwater recharge was evident. While outflow reduced significantly, groundwater recharge increased, implying that the AWM interventions have a positive impact on groundwater recharge. While there was about $50-70 \mathrm{~mm}$ of groundwater recharge during wet years under a nonintervention scenario, recharge was in the range of $150 \mathrm{~mm}$ to $200 \mathrm{~mm}$ with interventions. The base flow duration, which used to be 10-15 days before the intervention, increased to 30-40 days after the project interventions.

Figure 8 shows clear evidence of groundwater availability from measured water table data collected from the treated watershed and the control watershed. Both watersheds, however, showed a similar pattern during the monsoon. There was remarkable difference in water availability after the post-monsoon period. For example, in January 2004, there was a 10-m difference in water table between treated and control watersheds. This difference was found to be $3 \mathrm{~m}$ during the driest month of May. Similar observations were made in 2005. During the post-rainy season, most of the wells, which were either drying or had little water (1-3 m) were rejuvenated with surplus amount as the average water table increased by
5-8 m. Interestingly, nearly $30 \%$ of the wells, which were functioning during the monsoon period, turned into perennial sources of water for both domestic and agriculture use.

With increased water availability in the watershed, farmers were able to pump groundwater between 7-11 h/day compared to $1-4 \mathrm{~h} /$ day before the interventions during the rainy and post-rainy seasons, respectively. Due to increased recharge capacity, a decline was observed in the well recovery time after pumping, from $14 \mathrm{~h}$ to $10 \mathrm{~h}$ during the rainy season. A similar pattern was observed during the post-rainy and summer seasons; the recovery period fell by $5 \mathrm{~h}$ and $9 \mathrm{~h}$, respectively (Table 3 ). Increased water availability has facilitated supplemental irrigation at critical stages and the average area supported by a well for supplemental irrigation increased by three times compared to the nonintervention stage.

The total storage capacity of storage structures was equivalent to $32 \mathrm{~mm}$ of water depth. Figure 9 shows that the number of fillings varied from 1-10 depending on their location and storage capacity. The storage structures were categorized into five groups based on the number of fillings. Structures with smaller capacity generally got filled more often and the amount of inflow was several times more than that of bigger structures. The runoff generated from low intensity rainfall was sufficient to fill small structures. Structures located downstream of the bigger structure had less opportunity to receive inflows (e.g., S10). On an average, these structures filled up 3-3.5 times in wet years and 1-2.5 times in dry and normal years.

Figure 10a shows the runoff generated at the outlet of the watershed between 2000 and 2010 and the monthly rainfall under both intervention and nonintervention conditions. There was a significant reduction in the outflow due to upstream AWM interventions. A reduction of about $30-40 \%$ in outflow during wet and normal years and more than $70 \%$ during dry years was observed. Outflow was found proportional to rainfall received.

Figure 10b shows simulated cumulative sediment load between 2000 and 2011 at the outlet of the watershed under nonintervention and intervention condition. AWM interventions were found very effective in controlling soil loss. Cumulative soil loss at the outlet with no intervention was estimated to be about $17,000 \mathrm{t}$ in a 10 -year period while it was only about $4000 \mathrm{t}$ after the intervention. In other words, soil loss reduced from about 3.4 t/ha to $0.8 \mathrm{t} / \mathrm{ha}(76 \%)$ due to various AWM interventions.

Figure 11 shows spatial variability in the runoff coefficient from upstream to downstream areas in relation to the reservoir locations during dry, normal, and wet years. The runoff coefficient varied from 0.1 to 0.4. In general, runoff from the first order (upper most channels in a drainage network) streams/upstream locations (e.g., S7, S11, S12) was relatively higher than those from the downstream locations (e.g., S6, S9, S10, S13) due to upstream harvesting. Upstream sites are characterized by greater land slope and have shallow soil depth. The runoff generated from such HRUs was found to be $30-40 \%$ 


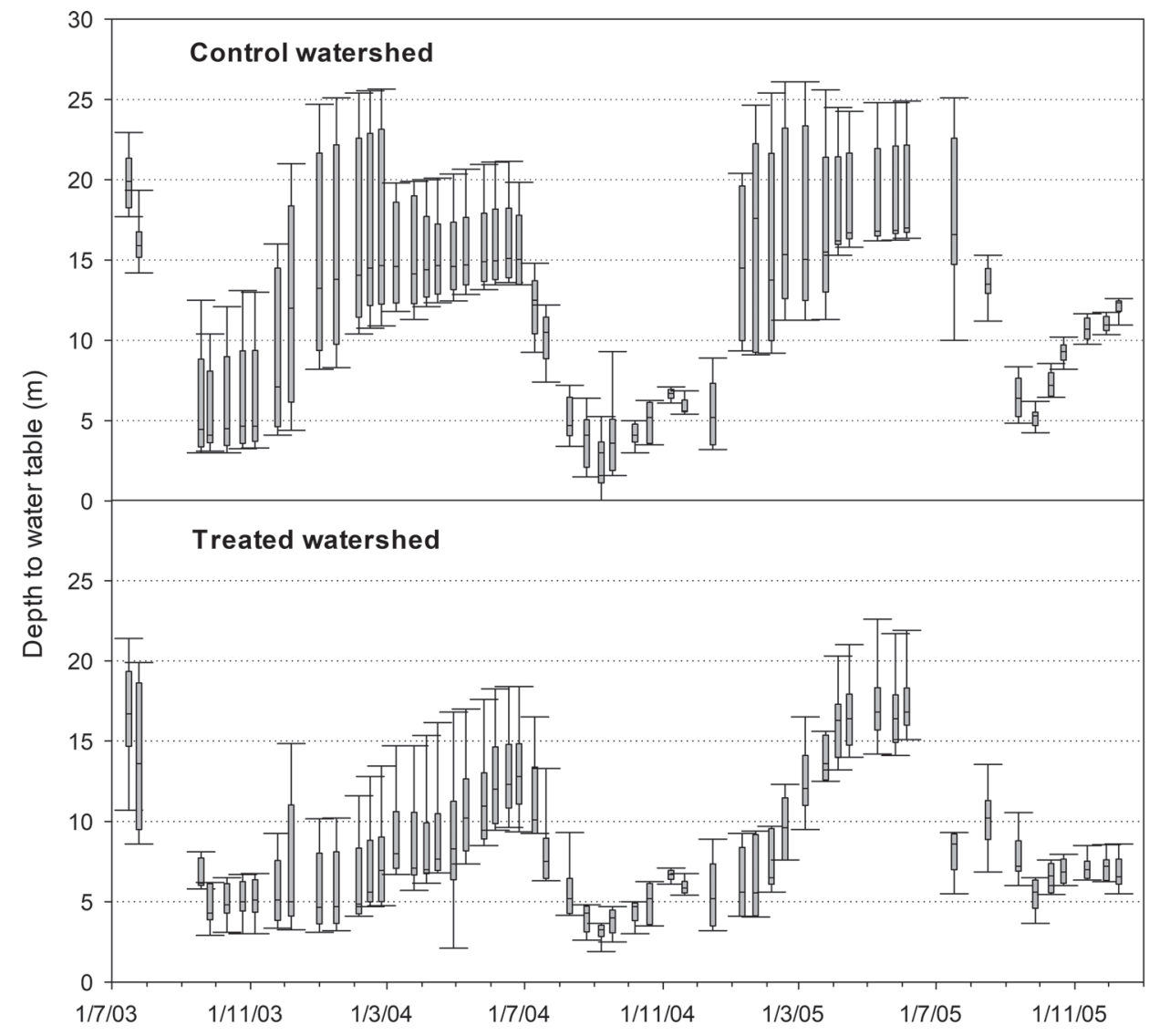

Figure 8. Comparing fluctuations in the depth of the water table in the treated (Govardhanapura-Thana) watershed and control watershed between 2003 and 2005 (data based on 20 monitoring wells).

Table 3

Impact of Interventions on Groundwater Yield in the Watershed (Data Based on Field Observation)

\begin{tabular}{|c|c|c|c|c|c|c|}
\hline \multirow[b]{2}{*}{ Season } & \multicolumn{2}{|c|}{$\begin{array}{l}\text { Pumping } \\
\text { Duration (h/day) }\end{array}$} & \multicolumn{2}{|c|}{$\begin{array}{l}\text { Recharge } \\
\text { Recovery Period (h) }\end{array}$} & \multicolumn{2}{|c|}{$\begin{array}{l}\text { Avg. Area Irrigated } \\
\text { by Well (ha) }\end{array}$} \\
\hline & Before Int. & After Int. & Before Int. & After Int. & Before Int. & After Int. \\
\hline Rainy & 4 & 11 & 13.5 & 10 & 1 & 2.5 \\
\hline Post-rainy & 1.5 & 6.5 & 21 & 16 & 0.5 & 1.5 \\
\hline Summer & 0 & 1 & 30 & 21 & 0 & 0.2 \\
\hline
\end{tabular}

Int $=$ intervention.

of the rainfall received. The runoff coefficients were found high in wet years compared to normal and dry years. Of the 13 structure sites, the runoff coefficient for three structures was over 0.4 ; five structures had a runoff coefficient between 0.2 and 0.4 ; and the rest had a runoff coefficient of less than 0.2. The overall runoff coefficient of the watershed (S13) was between 0.1 and 0.2 in all years.

\section{Uncertainties in the Model Results}

Efforts were made to collect a good amount of data on the physical properties of soils (texture, water-holding capacity, and soil depth), and the model was successfully calibrated. However, a number of uncertainties exist due to complex interactions between land use, land cover, topography, and soil type. Moreover, the percolation behavior of different reservoir sites also influenced inflow and outflow, which may lead to uncertainty in water balance analysis. It may be noted that the model takes into account the constant infiltration rate of the storage structures while it varies within the monsoon period; this could lead to inaccurate estimation of deep percolation and groundwater recharge. The study assumed default parameters of shrub/rangelands (crop parameters) during model development. Moreover, while developing the model, we considered maize/wheat as a dominant cropping system whereas the project area is characterized by a wider range of cropping systems and management practices. 
(a)

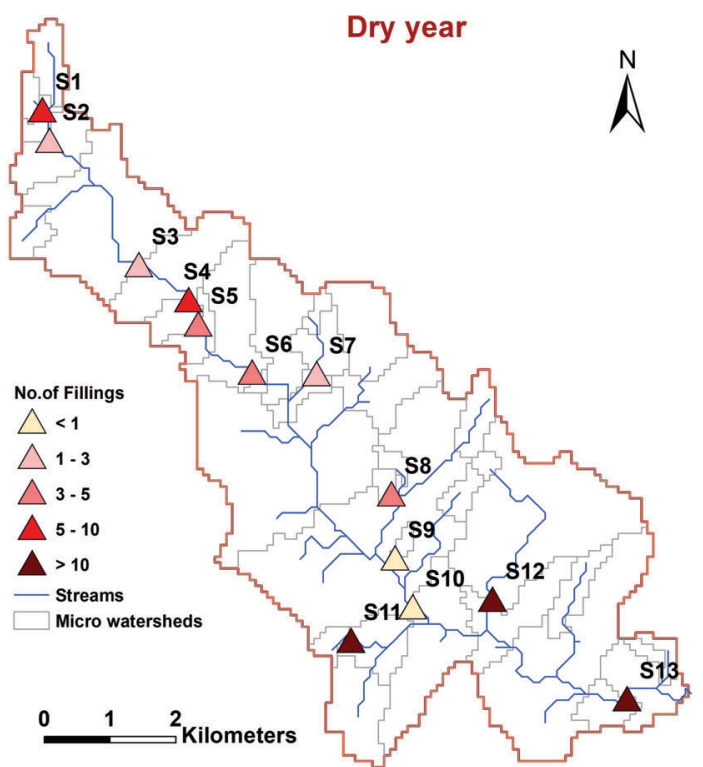

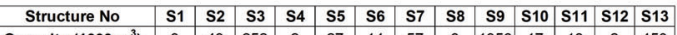
\begin{tabular}{|l|l|l|l|l|l|l|l|l|l|l|l|l|l|} 
Capacity $\left(1000 \mathrm{~m}^{3}\right)$ & 3 & 48 & 252 & 2 & 27 & 14 & 57 & 6 & 1356 & 17 & 18 & 2 & 450 \\
\hline
\end{tabular}

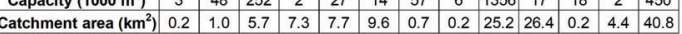

(b)

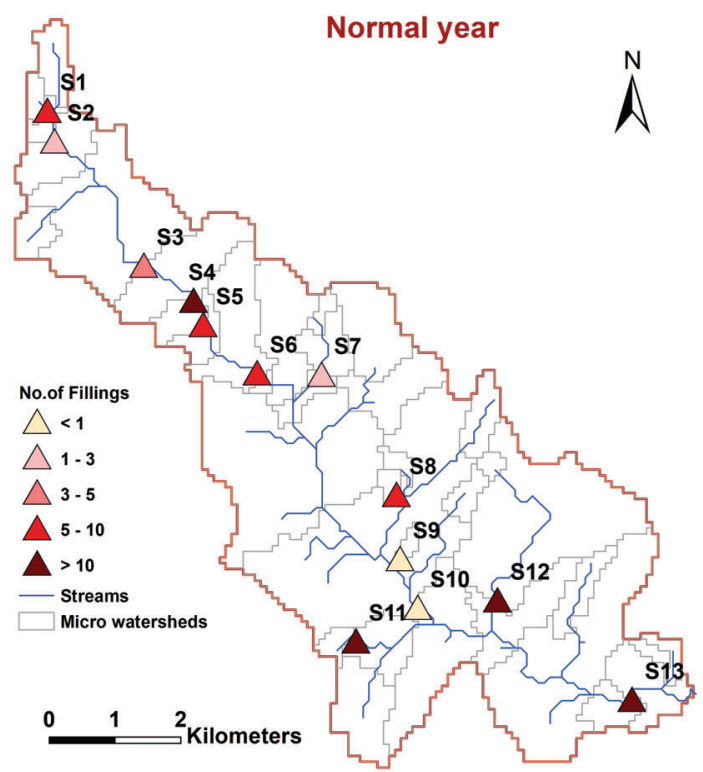

(c)

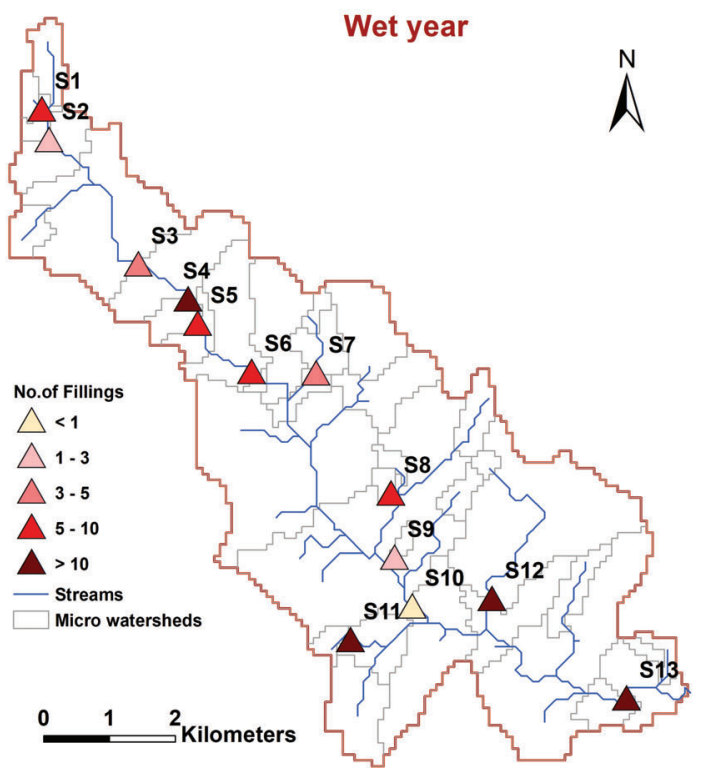

Figure 9. Variation in the number of fillings of storage structures at different locations during (a) dry, (b) normal, and (c) wet years.

\section{Impact on Crop Intensification and Crop Yield}

AWM interventions in the treated watershed recorded increased water availability, which translates to intensifying cropping systems during both rainy and post-rainy seasons. Figure 12a and $\mathrm{b}$ show the area under different crops before (1999) and after the interventions (2004), both during rainy and post-rainy seasons, respectively. A significant amount of cultivable fallow land (nearly 25-30\% both in rainy and post-rainy seasons) was converted into productive agricultural land. About $10 \%$ of fallow land has been used for horticulture crops during the monsoon and the rest has been utilized for vegetable cultivation during the post-rainy season. During the summer season, about $40-50$ ha was also used for green fodder production.

Figure 13 shows the increase in crop yields before and after the interventions during rainy and post-rainy seasons. Crop yields increased from $40 \%$ to $300 \%$ over several crops - from $1050 \mathrm{~kg} / \mathrm{ha}$ to $3200 \mathrm{~kg} / \mathrm{ha}$ in maize (rainy); $3000 \mathrm{~kg} / \mathrm{ha}$ to $5600 \mathrm{~kg} / \mathrm{ha}$ in wheat (post-rainy); $1500 \mathrm{~kg} / \mathrm{ha}$ to $2300 \mathrm{~kg} / \mathrm{ha}$ in mustard (post-rainy); and $950 \mathrm{~kg} / \mathrm{ha}$ to $1500 \mathrm{~kg} / \mathrm{ha}$ in chickpea (post-rainy) after project interventions. With increased water availability, the area grown to vegetables as well as yields nearly doubled $(4000 \mathrm{~kg} / \mathrm{ha}$ to $7500 \mathrm{~kg} / \mathrm{ha}$ ). With increased cropping 
(a)

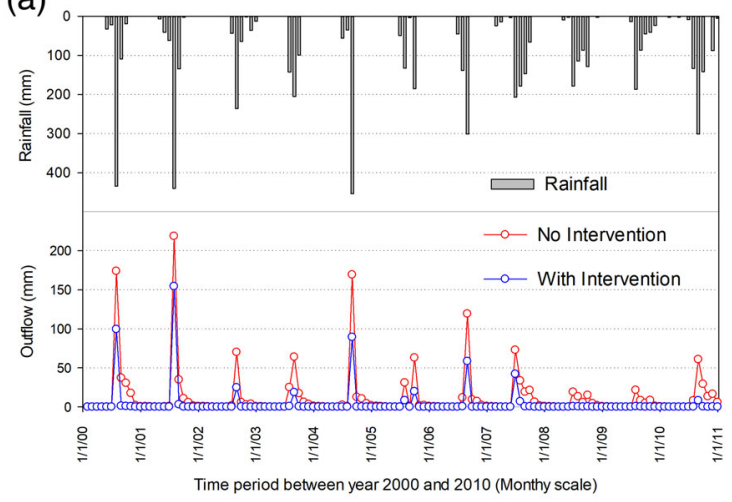

(b)

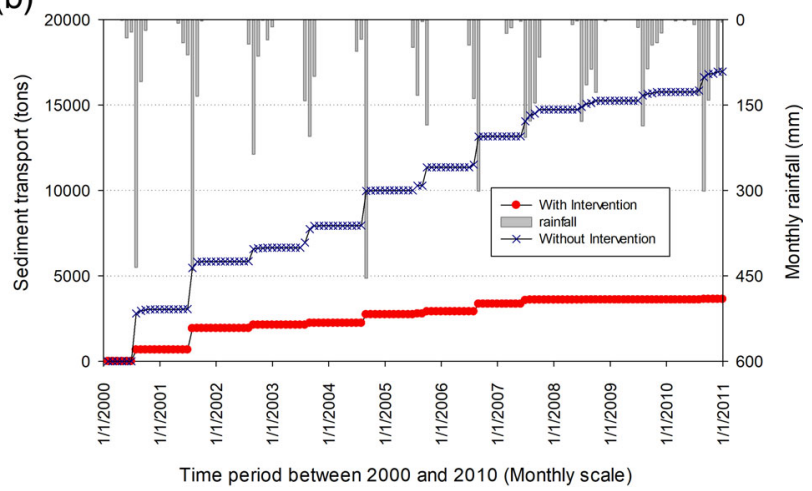

Figure 10. (a) Outflow generated from the watershed before and after the interventions (results based on a 11-year model simulation) and (b) cumulative simulated sediment $(t)$ transported at the watershed outlet with and without AWM interventions between 2000 and 2011.

intensity and productivity, the net income from the agriculture sector increased manifold. Average household income from agriculture was US\$300/year before the intervention and increased to US $\$ 1200 /$ year after the intervention.

\section{Discussion}

\section{Opportunity for Sustainable Crop Intensification}

It is evident that the AWM interventions in the study watershed have altered hydrological processes. About $40 \%$ of the total rainfall was generated as surface runoff before watershed interventions, which was flowing to the downstream area. There was little (less than 5\%) groundwater recharge. Following AWM interventions, the situation was reversed. Out of the total runoff generated, more than 50\% was harvested within the watershed and the rest flowed downstream. This has had a positive impact on groundwater recharge and has contributed to crop intensification. The results showed that altogether $150 \mathrm{~mm}$ of additional water is now being harvested and consumed for agriculture. The additional water harvesting increased total production from agriculture significantly. In this watershed, a large-scale upstream landscape (rangeland) was the major source of freshwater in the valley. As the soil depth and water-holding capacity of the rangeland is relatively poor, more than $50 \%$ of rainfall is generated as runoff. AWM interventions provided the opportunity to harvest the runoff and allowed farmers to cultivate nearby fields using supplemental irrigation. Over 150 ha was brought under productive cultivation with assured groundwater availability. A good amount of surface runoff was generated even in dry years. However, downstream release was most affected by upstream water harvesting.

\section{Upstream-Downstream Trade-Offs}

The findings of the study raise concerns about downstream water availability, as the upstream area was the main beneficiary. There could be trade-offs between development of upstream ecosystems and downstream water availability. AWM interventions in upstream enhance productivity, control flooding, enhance base flow, and control erosion and land degradation. The results clearly showed more than $75 \%$ reduction in soil loss with AWM interventions. Heavy sedimentation is one of the major concerns for downstream stakeholders (e.g., reservoir operators and managers) as the storage capacity of most of the reservoirs in India (e.g., dams) has fallen by $20 \%$ compared to the last three to four decades (Durbude 2014; Shukla et al. 2017). Heavy sedimentation transports important nutrients such as nitrogen, phosphorus, and other minerals from agriculture fields and pollutes downstream water bodies, which result in eutrophication and poor water quality (Haregeweyn et al. 2019). In surface water irrigation projects located at downstream areas (i.e., large dams) in ecologies (arid/semi-arid tropics) where evaporation rates are very high, nearly $20-30 \%$ of the stored water is lost due to evaporation losses (Mittal et al. 2017; Ates et al. 2020). AWM interventions at upstream locations provide opportunities to enhance groundwater recharge and reduce such losses to improve system-level efficiency.

Blue water (groundwater and surface runoff) is most sensitive to rainfall variability. Inevitably, a large portion of rainfall received goes toward ET. The remaining amount generates blue water, which again depends on landscape management. Before the intervention, surplus water was observed in the form of surface runoff, whereas it was partitioned into surface runoff and groundwater recharge after the intervention. About $80-120 \mathrm{~mm}$ of surplus water that is stored as groundwater (a reliable source) is available to various stakeholders. AWM interventions seem to have built a resilient groundwater system. A given amount of surplus water, if available as groundwater, can stay longer and is readily available. Field data show that if it is recharged once in a year, it is sufficient for subsequent years (Garg et al. 2020a). Groundwater carried over from the previous year alleviates stress conditions in subsequent dry years and serves as an important resilience building strategy against drought.

The study also quantifies the number of times a structure is filled during the monsoon period. The high level of percolation in this watershed repeatedly provided opportunities to harvest surface runoff within the monsoon 
(a)

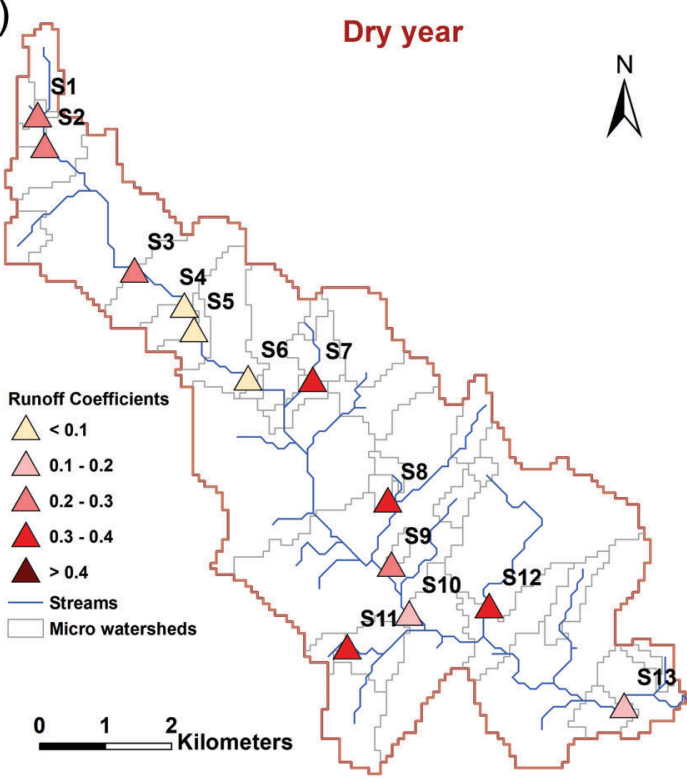

\begin{tabular}{|l|l|l|l|l|l|l|l|l|l|l|l|l|l|} 
Structure No & S1 & S2 & S3 & S4 & S5 & S6 & S7 & S8 & S9 & S10 & S11 & S12 & S13 \\
\hline
\end{tabular} \begin{tabular}{l|l|l|l|l|l|l|l|l|l|l|l|l|l|} 
Capacity $\left(1000 \mathrm{~m}^{3}\right)$ & 3 & 48 & 252 & 2 & 27 & 14 & 57 & 6 & 1356 & 17 & 18 & 2 & 450 \\
\hline
\end{tabular}

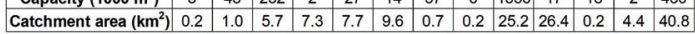

(b)

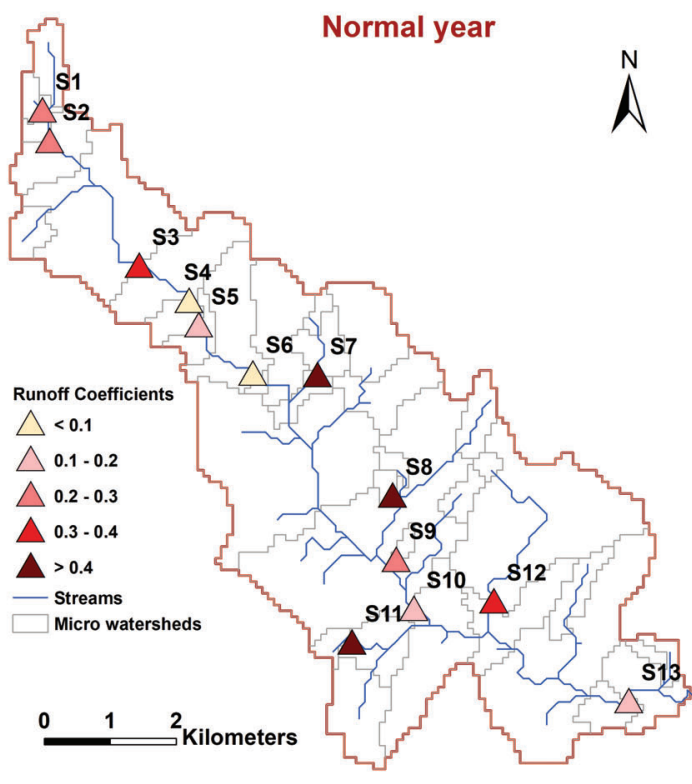

Wet year

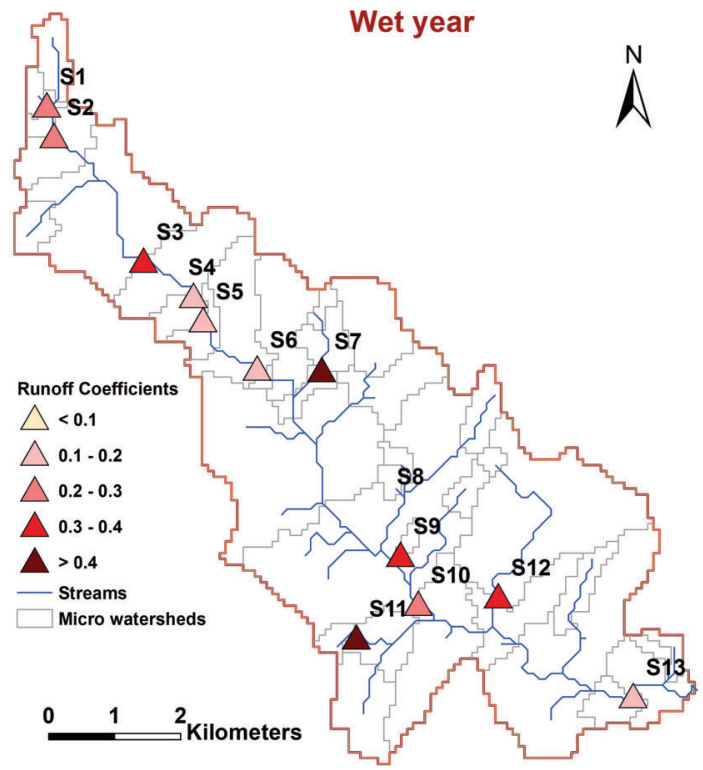

Figure 11. Variability in runoff coefficients at upstream and downstream locations during (a) dry, (b) normal, and (c) wet years.

period. A few structures filled up more than 10 times in a year while some filled up a fewer number of times, all depending on their location and storage capacity. For example, three out of 13 structures had storage capacity of more than 0.3 MCM though the amount of inflow was not of the same magnitude. Therefore, these structures were filled less than once whereas a few of the structures with storage capacity between 3000 and $10,000 \mathrm{~m}^{3}$ and inflow was several folds higher, providing the opportunity to fill up frequently. However, the steep topography was one of the important factors keeping the hydraulic gradient high, affecting the spatial level of infiltration across the landscape. On an average, these structures were filled two to three times in a normal year.

\section{Comparison with Other Studies}

The findings of this watershed are different from those on agriculture-dominant watersheds. The latter are relatively flatter, intensively cultivated, and have limited scope to generate surplus water, with only the wet years providing the opportunity for water harvesting (Garg et al. 2020a). There are a number of studies on regional scale water balance but very few attempt to understand mesoscale water balance components. Analyzing the 


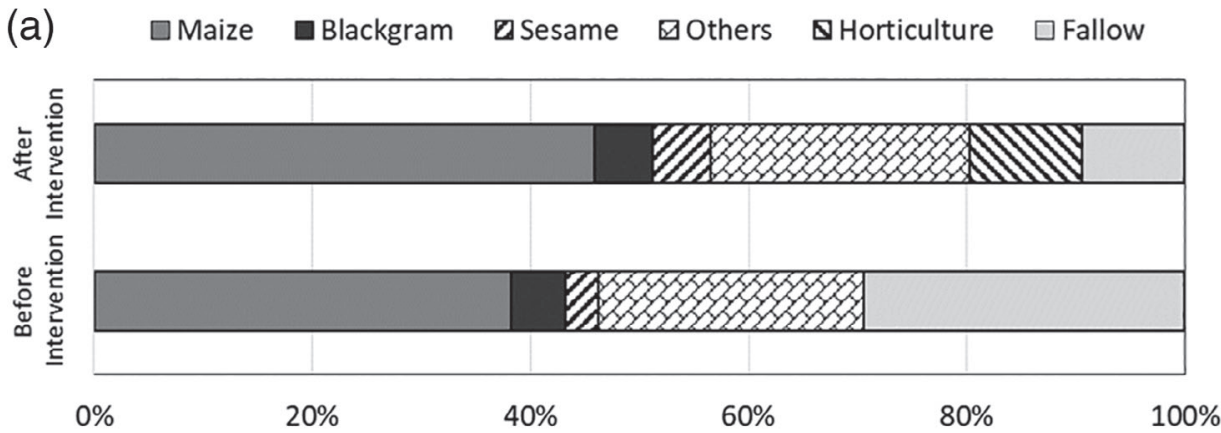

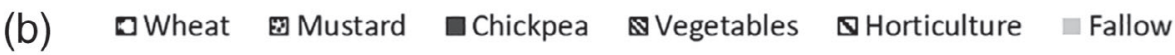

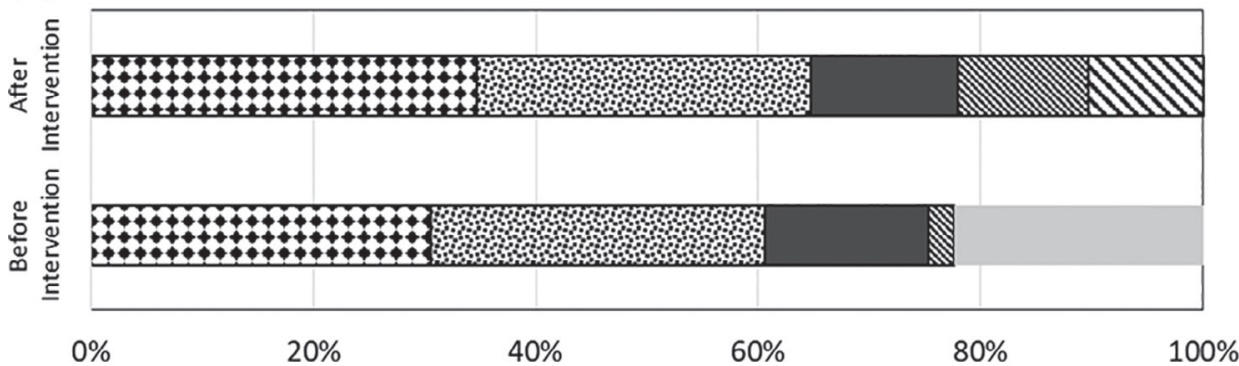

Figure 12. Area (\%) under cultivation during the (a) rainy season and (b) post-rainy season before and after the interventions (data based on field records).

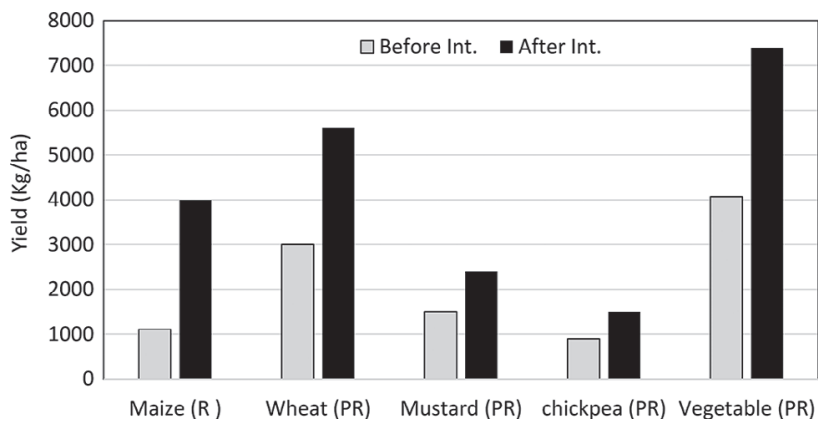

Figure 13. A comparison of yields of major crops before and after watershed interventions; crop yields were measured based on crop cutting studies from select farmer fields.

water balance components of AWM interventions in a similar ecological system of a fragile landscape in Udaipur, Rajasthan state, Dashora et al. (2019) found that AWM interventions were maximizing groundwater recharge and refilling four times their capacity in a wet year. Glendenning and Vervoort (2010) have reported that AWM interventions helped enhance groundwater availability and mitigate the risk of crop failure in Arvari catchment, Rajasthan. However, a significant decline in downstream water availability due to upstream AWM interventions was the major concern. They also found that there is a limited scope of groundwater recharge after crossing a threshold as increasing the size of various structures does not always contribute to groundwater recharge (Glendenning and Vervoort 2010). Rather, it negatively impacts downstream flow, contrary to the current study in which large-scale harvesting did not limit groundwater recharge due to the higher slope gradient.

\section{Future Scope}

Adequate moisture availability is required for crop intensification in drylands. AWM interventions has ensured the availability of supplemental irrigation. The additional resources required for ensuring moisture availability are generated within the landscape. This study shows both upstream benefits and the consequences on downstream communities. The study will be useful to understand hydrological processes and take informed decisions on optimizing available resources in a fragile landscape. Though landscape hydrology is complex to model due to the heterogeneity in the topography, soil types, rainfall, land use, and management practices, an effort was made to do so by using field measurements and simulation modeling. There is also scope to quantify the economic benefits generated due to various AWM interventions and do a cost-benefit analysis. With technological advancements in the areas of monitoring and evaluation, it has become possible to capture impact more accurately; a comparison could be done with and without interventions and also before and after the project interventions. Similar efforts are needed for different agro-ecological regions to bridge the knowledge gap and to facilitate informed decisions.

\section{Conclusion}

The study analyzed the impact of decentralized AWM interventions in a fragile watershed in western India following a ridge-to-valley approach to construct storage structures. This watershed was monitored intensively and a number of parameters, including biophysical, 
meteorological, hydrological, crop productivity, land-use change, soil loss, and socio-economic characteristics were collected between 2000 and 2006. This data was used to calibrate a hydrological model and the results were simulated between 2000 and 2010 to capture rainfall variability. The impact of AWM interventions on watershed hydrology and different water balance components was analyzed. The key findings are:

- Water balance: Of the $500 \mathrm{~mm}$ rainfall received during a normal year, $300 \mathrm{~mm}(60 \%)$ was utilized as ET, $150 \mathrm{~mm}$ generated as surface runoff, and the rest was recharging groundwater before the project interventions.

- AWM interventions have helped enhance groundwater recharge by more than double compared to nonintervention conditions. However, it did reduce surface runoff by more than $50 \%$. The outflow from the watershed was reduced by over $70 \%$ in dry and normal years and by $50 \%$ in wet years. However, the AWM interventions reduced sediment loading by more than $75 \%$ compared to nonintervention conditions.

- Water storage structures were filled up an average of two to three times depending on rainfall and inflow generated. The number of fillings were largely dependent on the location of the structure in terms of toposequence and its size.

- Groundwater augmentation has helped enhance crop intensification, reduced the risk of crop failure and enhanced crop yields from 50 to $300 \%$. The additional area was brought under cultivation with assured water availability. This enhanced farmers' incomes by three to five times.

The findings of the study would be helpful to stakeholders in making informed decisions while planning AWM interventions by considering their consequences on downstream communities.

\section{Acknowledgments}

The financial support provided by Sir Dorabji Tata Trust for the development of the Govardhanapura-Thana Watershed at Bundi, Rajasthan, is gratefully acknowledged. The CGIAR Research Program-Water, Land, and Ecosystems' (WLE) support for ICRISAT scientists' time to analyze historical data is duly acknowledged. The authors would also like to thank both the reviewers, Dr Sreekanth Janardhanan and Dr John McCray, for providing very insightful comments and suggestions to improve the manuscript.

\section{Authors' Note}

The authors do not have any conflicts of interest or financial disclosures to report.

\section{References}

Abera, W., L. Tamene, D. Tibebe, Z. Adimassu, H. Kassa, H. Hailu, K. Mekonnen, G. Desta, R. Summer, and
L. Vercho. 2019. Characterizing and evaluating the impacts of national land restoration initiatives on ecosystem services in Ethiopia. Land Degradation and Development 31, no. 1: $37-52$.

Abraham, A., and P. Ramachandran. 2020. The welfare implications of transboundary storage and dam ownership on river water trade. Mathematical Social Sciences 109: $18-27$

Adimassu, Z., S. Langan, R. Johnston, W. Mekuria, and T. Amede. 2017. Impacts of soil and water conservation practices on crop yield, run-off, soil loss and nutrient loss in Ethiopia: Review and synthesis. Environmental Management 59: 87-101.

Ali, H., P. Modi, and V. Mishra. 2019. Increased flood risk in Indian sub-continent under the warming climate. Weather and Climate Extremes 25: 100212.

Anantha, K.H., K.K. Garg, C.A. Petrie, and S. Dixit. 2021 a. Seeking sustainable pathways for fostering agriculture transformation in Peninsular India. Environmental Research Letters. https://doi.org/10.1088/1748-9326/abed7b

Anantha, K.H., K.K. Garg, S.D. Moses, M.D. Patil, G.L. Sawargaonkar, P. Kamdi, S. Malve, R. Sudi, K.V. Raju, and S.P. Wani. 2021b. Impact of natural resource management interventions on water resources and environmental services in different agroecological regions of India. Groundwater for Sustainable Development 13: 100574.

Anantha, K.H., and S.P. Wani. 2016. Evaluation of cropping activities in the Adarsha watershed project, southern India. Food Security 8, no. 5: 885-897.

Arnold, J.G., D.N. Moriasi, P.W. Gassman, K.C. Abbaspour, M.J. White, R. Srinivasan, C. Santhi, R.D. Harmel, A. van Griensven, M.W.V. Liew, N. Kannan, and M.K. Jha. 2012. SWAT: Model use, calibration, and validation. Transactions of the ASABE 55, no. 4: 1491-1508.

Ates, A.M., O.S. Yilmaz, and F. Gulgen. 2020. Using remote sensing to calculate floating photovoltaic technical potential of a dam's surface. Sustainable Energy Technologies and Assessments 41: 100799.

Bahar, N.H.A., M. Lo, M. Sanjaya, J.V. Vianen, P. Alexander, A. Ickowitz, and L. Sunder. 2020. Meeting the food security challenge for nine billion people in 2050: What impact on forests? Global Environmental Change 62: 102056.

Barron, J., E. Kemp-Benedict, J. Morris, A. de Bruin, G. Wang, and A. Fencl. 2015. Mapping the potential success of agricultural water management interventions for smallholders: Where are the best opportunities? Water Resources and Rural Development 6: 29-49.

Berihun, M.L., A. Tsunekawa, N. Haregeweyn, Y.T. Dile, M. Tsubo, A.A. Fenta, D.T. Meshesha, K. Ebabu, D. Sultan, and R. Srinivasan. 2020. Evaluating runoff and sediment responses to soil and water conservation practices by employing alternative modeling approaches. Science of the Total Environment 747: 141118.

Biswadeep, B. 2015. Estimation of reservoir storage capacity by using residual mass curve. Journal of Civil Engineering and Environmental Technology 2, no. 10: 15-18.

Black, T.A., and C.H. Luce. 2013. Measuring Water and Sediment Discharge from a Road Plot with a Settling Basin and Tipping Bucket. General Technical Report RMRS GTR-287. Fort Collins, Colorado: U.S. Department of Agriculture, Forest Service, Rocky Mountain Research Station.

Dashora, Y., P. Dillon, B. Maheshwari, P. Soni, H.K. Mittal, R. Dashora, P.K. Singh, R.C. Purohit, and P. Katara. 2019. Hydrologic and cost benefit analysis at local scale of streambed recharge structures in Rajasthan (India) and their value for securing irrigation water supplies. Hydrogeology Journal 27: 1889-1909.

de Fraiture, C., D. Molden, and D. Wichelns. 2010. Investing in water for food, ecosystems, and livelihoods: An overview 
of the comprehensive assessment of water management in agriculture. Agricultural Water Management 97: 495-501.

de Janvry, A., and E. Sadoulet. 2020. Using agriculture for development: Supply- and demand-side approaches. World Development 133: 105003.

Dile, Y.T., L. Karlberg, P. Daggupati, R. Srinivasan, D. Wiberg, and J. Rockström. 2016a. Assessing the implications of water harvesting intensification on upstream-downstream ecosystem services: A case study in the Lake Tana basin. Science of the Total Environment 542: 22-35.

Dile, Y., R. Srinivasan, and L. Karlberg. 2016b. Assessing the implications of water harvesting intensification on upstream-downstream social-ecological resilience: A case study in the Lake Tana Basin. Science of the Total Environment 542: 22-35.

Durbude, D.G. 2014. Assessment of sedimentation in major reservoirs of hard rock terrain of India using RS technique. Earth Sciences Research Journal 2, no. 1: 13.

Duro, J.A., C. Lauk, T. Kastner, K.H. Erb, and H. Haberl. 2020. Global inequalities in food consumption, cropland demand and land-use efficiency: A decomposition analysis. Global Environmental Change 64: 102124.

FAO. 2020. The State of Food and Agriculture 2020. Overcoming Water Challenges in Agriculture. Rome, France: FAO. https://doi.org/10.4060/cb1447en

Garg, K.K., R. Singh, K.H. Anantha, A.K. Singh, A. Venkataradha, J. Barron, D. Inder, R.K. Tewari, S.P. Wani, S.K. Dhyani, and D. Sreenath. 2020a. Impact of agricultural water management interventions on hydrological processes, crop intensification and agricultural productivity: A study in a meso-scale watershed, Bundelkhand region, Central India. Journal of Hydrology 591: 125592.

Garg, K.K., K.H. Anantha, R. Nune, A. Venkataradha, P. Singh, M.K. Gumma, S. Dixit, and R. Ragab. 2020b. Impact of land use changes and management practices on groundwater resources in Kolar district, southern India. Journal of Hydrology: Regional Studies 31: 100732.

Garg, N.K., and S. Azad. 2019. Analysis of Cauvery watersharing award using an analytical framework model. Journal of Hydrology 579: 124214.

Garg, K.K., and S.P. Wani. 2012. Opportunities to build groundwater resilience in the semi-arid tropics. Groundwater 51, no. 5: 679-691.

Garg, K.K., S.P. Wani, J. Barron, L. Karlberg, and J. Rockstrom. 2012. Up-scaling potential impacts on water flows from agricultural water interventions: Opportunities and tradeoffs in the Osman Sagar catchment, Musi sub-basin, India. Hydrological Processes 27, no. 26: 3905-3921.

Garg, K.K., L. Karlberg, J. Barron, S.P. Wani, and J. Rockstrom. 2011. Assessing impact of agricultural water interventions at the Kothapally watershed, southern India. Hydrological Processes 26, no. 3: 387-404.

Gerten, D., V. Heck, J. Jägermeyr, B.L. Bodirsky, I. Fetzer, M. Jalava, M. Kummu, W. Lucht, J. Rockström, S. Schaphoff, and H.J. Schellnhuber. 2020. Feeding ten billion people is possible within four terrestrial planetary boundaries. Nature Sustainability 3: 200-208.

Gleeson, T., K.M. Befus, S. Jasechko, E. Luijendijk, and M.B. Cardendas. 2016. The global volume and distribution of modern groundwater. Nature Geoscience 9, no. 2: $161-167$.

Glendenning, C.J., F.F. van Ogtrop, A.K. Mishra, and R.W. Vervoort. 2012. Balancing watershed and local scale impacts of rain water harvesting in India-: A review. Agricultural Water Management 107: 1-13.

Glendenning, C.J., and R.W. Vervoort. 2010. Hydrological impacts of rainwater harvesting $(\mathrm{RWH})$ in a case study catchment: The Arvari River, Rajasthan, India. Part 1: Field-scale impacts. Agricultural Water Management 98: $331-342$.
Gordon, L.J., C.M. Finlayson, and M. Falkenmark. 2010. Managing water in agriculture for food production and other ecosystem services. Agricultural Water Management 97: $512-519$.

Government of India. 2019. National Compilation on Dynamic Ground Water Resources of India, 2017. Faridabad, India: Ministry of Jal Shakti Department of Water Resources, RD \& GR Central Ground Water Board.

Green, A.S., S. Dixit, K.K. Garg, N.R. Sandya, G. Singh, K. Vatta, A.M. Whitbread, M.K. Jones, R.N. Singh, and C.A. Petrie. 2020. An interdisciplinary framework for using archaeology, history and collective action to enhance India's agricultural resilience and sustainability. Environmental Research Letters 15, no. 10: 105021.

Haregeweyn, N., A. Tsunekawa, J. Poesen, M. Tsubo, D.T. Meshesha, A.A. Fenta, J. Nyssen, and E. Adgi. 2019. Comprehensive assessment of soil erosion risk for better land use planning in river basins: Case study of the Upper Blue Nile River. Science of the Total Environment 574: 95-108.

Hoekstra, A.Y., and M.M. Mekonnen. 2012. The water footprint of humanity. PNAS 9, no. 109: 3232-3237.

Horan, R., R. Gowri, P.S. Wable, H. Baron, V.D.J. Keller, K.K. Garg, P.P. Mujumdar, H. Houghton-Carr, and G. Rees. 2021. A comparative assessment of hydrological models in the Upper Cauvery catchment. Water 13, no. 2: 151-175.

Kadyampakeni, D., S. Kazombo-phiri, B. Mati, and I.R. Fandika. 2015. Performance of small-scale water management interventions on crop yield, water use and productivity in three agro-ecologies of Malawi. Irrigation and Drainage 64: 215-227.

Kato, E., D. Mekonnen, S. Tiruneh, and C. Ringler. 2019. Sustainable Land Management and Its Effects on Water Security and Poverty: Evidence from a Watershed Intervention Program in Ethiopia. IFPRI Discussion Paper 1811. Washington, DC: International Food Policy Research Institute.

Mekonnen, D.F., Z. Duan, T. Rientjes, and M. Disse. 2018. Analysis of combined and isolated effects of land-use and land-cover changes and climate change on the upper Blue Nile River basin's streamflow. Hydrology and Earth System Sciences 22: 6187-6207.

Michler, J.D. 2020. Agriculture in the process of development: A micro-perspective. World Development 129: 104888.

Mittal, D., B.K. Saxena, and K.V.S. Rao. 2017. Comparison of floating photovoltaic plant with solar photovoltaic plant for energy generation at Jodhpur in India. 2017 International Conference on Technological Advancements in Power \& Energy (TAP Energy), IEEE, 1-6.

Mondal, B., N. Loganandhan, S.L. Patil, A. Raizada, S. Kumar, and G.L. Bagdi. 2020. Institutional performance and participatory paradigms: Comparing two groups of watersheds in semi-arid region of India. International Soil and Water Conservation Research 8, no. 2: 164-172.

Mukherjee, S., S. Aadhar, D. Stone, and V. Mishra. 2018. Increase in extreme precipitation events under anthropogenic warming in India. Weather and Climate Extremes 20: $45-53$.

Omer, A., N.A. Elagib, M. Zhuguo, F. Saleem, and A. Mohammed. 2020. Water scarcity in the Yellow River Basin under future climate change and human activities. Science of the Total Environment 749: 141446.

Pathak, P., K. Chandrasekhar, S.P. Wani, R.R. Sundi, and N. Budama. 2016. Integrated runoff and soil loss monitoring unit for small agricultural watersheds. Computers and Electronics in Agriculture 128: 50-57.

Pathak, P., A.K. Chourasia, S.P. Wani, and R. Sudi. 2013. Multiple impact of integrated watershed management in low rainfall semi-arid region: A case study from eastern Rajasthan, India. Journal of Water Resource and Protection 5: $27-36$. 
Pathak, P., S.P. Wani, R. Sudi, A.K. Chourasia, S.N. Singh, and A.V.R.K. Rao. 2007. Rural Prosperity through Integrated Watershed Management: A Case Study of GokulpuraGoverdhanpura in Eastern Rajsathan. Global Theme on Agroecosystems Report No. 36. Patancheru, India: International Crops Research Institute for the Semi-Arid Tropics (ICRISAT).

Rao, C.S., R. Lal, J. Prasad, K.A. Gopinath, R. Singh, V.S. Jakkula, K.L. Sahrawat, B. Venkateswarlu, A.K. Sikka, and S.M. Virmani. 2015. Potential challenges of rainfed farming in India. Advances in Agronomy 133: 113-181.

Rao, A.V.R.K., S.P. Wani, K.K. Singh, M.I. Ahmed, K. Srinivas, S.D. Bairagi, and O. Ramadevi. 2013. Increased arid and semi-arid areas in India with associated shifts during 1971-2004. Journal of Agrometeorology 15, no. 1: 11-18.

Rockström, J., L. Karlberg, S.P. Wani, J. Barron, N. Hatibu, T. Oweis, A. Bruggeman, J. Farahani, and Z. Qiang. 2010. Managing water in rainfed agriculture-The need for a paradigm shift. Agricultural Water Management 97: $543-550$.

Rockström, J., W. Steffen, K. Noone, Å. Persson, F.S. Chapin, E. Lambin, T.M. Lenton, M. Scheffer, C. Folke, H. Schellnhuber, B. Nykvist, C.A. De Wit, T. Hughes, S. van der Leeuw, H. Rodhe, S. Sörlin, P.K. Snyder, R. Costanza, U. Svedin, M. Falkenmark, L. Karlberg, R.W. Corell, V.J. Fabry, J. Hansen, B. Walker, D. Liverman, K. Richardson, P. Crutzen, and J. Foley. 2009. Planetary boundaries: Exploring the safe operating space for humanity. Ecology and Society 14, no. 2: 32.

Schaap, M.G., F.J. Leij, and M.T. van Genuchten. 2001. rosetta: A computer program for estimating soil hydraulic parameters with hierarchical pedotransfer functions. Journal of Hydrology 251, no. 3-4: 163-176.

Sharma, A., D. Sharma, S.K. Dubey, R.K. Pradhan, and S.K. Panda. 2018. Investigation of temperature and its indices under climate change scenarios over different regions of Rajasthan state in India. Global and Planetary Change 161: 82-96.

Shukla, S., S.K. Jain, M.L. Kansal, and S.K. Chandniha. 2017. Assessment of sedimentation in Pong and Bhakra reservoirs in Himachal Pradesh, India, using geospatial technique.
Remote Sensing Applications: Society and Environment 8: $148-156$.

Singh, R., K.K. Garg, S.P. Wani, R.K. Tewari, and S.K. Dhyani. 2014. Impact of water management interventions on hydrology and ecosystem services in Garhkundar-Dabar watershed of Bundelkhand region, Central India. Journal of Hydrology 509: 132-149.

Takal, K.M., A.R. Sorgul, and A.T. Balakarzai. 2017. Estimation of reservoir storage capacity and maximum potential head for hydro-power generation of propose Gizab Reservoir, Afghanistan, using mass curve method. International Journal of Advanced Engineering Research and Science 4, no. 11: 98-104.

Tek, B.S., M.L. Jat, R.K. Jat, P. Kapoor, and S. Clare. 2016. Yield estimation of food and non-food crops in smallholder production systems. In Methods for Measuring Greenhouse Gas Balances and Evaluating Mitigation Options in Smallholder Agriculture, ed. T.S. Rosenstock, M.C. Rufino, K. ButterbachBahl, E. Wollenberg, and M. Richards, 163-174. Cham: Springer.

Wani, S.P., G. Chander, and K.L. Sahrawat. 2014. Scienceled interventions in integrated watersheds to improve smallholders' livelihoods. NJAS - Wageningen Journal of Life Sciences 70: 71-77.

Wani, S.P., Y. Dixin, Z. Li, W.D. Dar, and G. Chander. 2011. Enhancing agricultural productivity and rural incomes through sustainable use of natural resources in the semiarid tropics. Journal of the Science of Food and Agriculture 92: 1054-1063.

Woldesenbet, T.A., N.A. Elagib, L. Ribbe, and J. Heinrich. 2018. Catchment response to climate and land use changes in the upper Blue Nile sub-basins, Ethiopia. Science of the Total Environment 644: 193-206.

Woldesenbet, T.A., N.A. Elagib, L. Ribbe, and J. Heinrich. 2017. Hydrological responses to land use/cover changes in the source region of the upper Blue Nile Basin, Ethiopia. Science of the Total Environment 575: 724-741.

Worku, T., D. Khare, and S.K. Tripathi. 2017. Modeling runoff-sediment response to land use/land cover changes using integrated GIS and SWAT model in the Beressa watershed. Environmental Earth Science 76: 1-14. 